\title{
Implementasi Metode Simple Additive Weighting Pada Aplikasi Rekomendasi Tempat Pengungsian Akibat Bencana Banjir
}

\author{
Angga Try Ramdany ${ }^{1}$, Eko Budi Setiawan ${ }^{2}$ \\ Program Studi Teknik Informatika, Universitas Komputer Indonesia \\ angga3399@gmail.com \\ eko@email.unikom.ac.id
}

Diterima 9 Maret 2019

Disetujui 24 Juni 2019

\begin{abstract}
BBWS Cimanuk-Cisanggarung is a technical implementation unit at the Directorate General of Water Resources, Ministry of Pekerjaan Umum and Perumahan Rakyat which has the task of carrying out water resources management in the river area. As for the background of this study is the difficulty of river field officers to notify the announcement to the people who will be affected by the flood due to overflowing rivers, because the announcement is still a simple medium that is using sirens and hoaxes or electric poles. Geotagging technology and Fire Cloud Messaging Technology (FCM) is one of the ways to help field officers make public announcements through smartphone media, namely notifications that include river photos and locations. The difficulty of the people who are close to the CimanukCisanggarung watershed to get information about evacuation places before the flood occurs, because many people choose a place of refuge with their own choice. This is what makes the government more extra to provide assistance to unknown refugee camps. Google Maps technology can help people get to refugee camps recommended by the government. This research method consists of identifying problems, methods of data collection, system analysis, system design, system implementation, testing, and drawing conclusions. The results of the study show that river field staff and the community can be used as a notification of the river that will overflow and provide information on the place of refuge.
\end{abstract}

Index Terms - FCM, Geotagging, Goggle Maps, Refuge, Notification

\section{PENDAhUlUAN}

Balai Besar Wilayah Sungai CimanukCisanggarung merupakan unit pelaksana teknik (UPT) pada Direktorat Jenderal Sumber Daya Air, Kementerian Pekerjaan Umum dan Perumahan Rakyat yang mempunyai tugas melaksanakan pengelolaan sumber daya air di wilayah sungai dan memberikan sebuah pengumuman kepada masyarakat setempat mengenai keadaan sungai. Pengumuman dapat diartikan sebagai pesan yang disampaikan kepada setiap orang yang menjadi setiap orang yang menjadi tujuan atau menjadi sasaran informasi yang dituju [1].
Di masa perkembangan teknologi yang terus meningkat, pemerintah terus mengembangkan suatu pekerjaannya dengan menggunakan teknologi Smartphone. Sistem dalam memberikan pengumuman sungai yang akan meluap saat ini kurang efektif dikarenakan masih menggunakan media yang sederhana sepeti kentungan atau tiang listrik dan sirine. Hal ini berpengaruh dalam pemberian pengumuman bagi masyarakat yang jauh dari petugas lapangan yang dikarenakan memiliki jangkauan yang tidak luas.

Berdasarkan hasil wawancara dengan bapak Dodo Wardoyo, S.T selaku petugas teknik di Operasi dan Pemeliharaan Sumber Daya Air III dan disetujui oleh I Gusti Ngurah Antariza, S.T.,M.T. selaku Penjabat Pembuat Komitmen dan Pemeliharaan SDA III, pada bulan Februari 2018. Adapun kendala yaitu sulitnya petugas lapangan sungai untuk memberitahukan pengumuman kepada masyarakat yang akan terkena dampak banjir karena luapan sungai yang berada di DAS Cimanuk-Cisanggarung, dikarenakan pengumuman masih media yang sederhana yaitu menggunakan sirine dan ketongan atau tiang listrik. Teknologi geotagging dan dan Teknologi Fire Cloud Messaging (FCM) merupakan salah satu untuk membantu petugas lapangan memberi pengumuman kepada masyarkat melalui media smartphone yaitu notifikasi yang disertakan foto sungai dan lokasinya.

Kendala lainnya yaitu sulitnya masyarakat yang dekat dengan DAS Cimanuk-Cisanggarung mendapatkan informasi tempat pengungsian sebelum terjadi banjir, dikarenakan banyak masyarakat memilih tempat pengungsian dengan pilihan sendiri. Hal demikian yang membuat pemerintah lebih ekstra untuk memberikan bantuan ke tempat pengungsian yang tidak diketahui. Teknologi Google Maps dapat membantu masyarakat menuju tempat pengungsian yang di rekomendasikan oleh pemerintah.

Adapun penelitian yang serupa yaitu, Fariz,dkk [2] mengenai penggunaan teknologi Firebase Cloud Messaging (FCM). Firebase Cloud Messaging mampu menjalankan fitur push notifikasi dan menerima 
notifikasi. Pada penelitian Wisnu,dkk [3], mengenai pemberitahuan bencana banjir dengan menggunakan fitur teknologi Geotagging, geotagging ini menyimpan titik lokasi yang kemudian dikelola menjadi suatu data informasi yang dapat digunakan untuk pembuatan sebuah peta kejadian bencana banjir. Pada penelitian Julia,dkk [4], membahas mengenai sistem informasi geografis dalam menentukan lokasi evakuasi bencana banjir dalam bentuk peta virtual yaitu Google Maps.

Dalam Pembangunan Aplikasi ini memanfaatkan smartphone Android, dikarenakan dari data website The Statistic Portal menunjukan pada bulan Desember 2017 bahwa sistem operasi Android paling banyak digunakan di Indonesia dengan persentase 88,37\%. [5]

FCM merupakan perkembangan dari Google cloud messaging [2]. Firebase Cloud Messaging (FCM) yang memiliki kemampuan untuk mengirim dan menerima notifikasi [6]. Petugas lapangan dapat mengirim notifikasi mengenai luapan sungai dan masyarakat menerima notifikasi mengenai daerahnya yang terkena luapan sungai beserta rekomendasi tempat pengungsian.

Google maps merupakan sebuah layanan peta dunia virtual yang tersedia di smartphone dan website [3] [7]. Google maps membantu masyarakat untuk memberikan pengarahan menuju tempat yang diinginkan. Sehingga masyarakat tidak akan tersesat ketika menuju lokasi. Selain itu Metode yang digunakan untuk jarak terdekat menggunakan metode Euclidean Distansce [8] dan metode Simple Additive Weighting [4] [9] [10] untuk perhitungan rekomendasi tempat pengungsian terbaik.

Dengan demikian, aplikasi rekomendasi tempat pengungsian yang dibangun dalam penelitian ini dapat mempermudah petugas lapangan sungai dalam memberikan pengumuman mengenai sungai yang akan meluap dan masyarakat dapat menerima informasi mengenai sungai yang akan meluap dan rekomendasi tempat pengungsian.

\section{TINJAUAN PUSTAKA}

\section{A. Teknologi Informasi}

Teknologi Informasi adalah kajian, desain, pengembangan implementasi, dukungan, atau manajemen sistem informasi yang berbasis komputer, khususnya aplikasi perangkat lunak dan perangkat keras [11]. Lebih lanjut, teknologi informasi berkaitan dengan penggunaan komputer dan perangkat lunak untuk mengubah, menyimpan, melindungi, memproses, memindah, dan menggunakan informasi secara aman. [12]

\section{B. Rekomendasi Tempat}

Rekomendasi tempat adalah saran tempat yang sifatnya menganjurkan, membenarkan, atau menguatkan mengenai tempat yang terbaik. Rekomendasi tempat ini sangat penting dan membantu masyarakat dalam meyakinkan memilih tempat. Dalam rekomendasi ini biasanya memiliki kriteria yang menjadi acuan utama, misal tempat yang nyaman atau tempat yang sering dipilih oleh orang lain. [13]

\section{Metode $S A W$}

Metode Simple Additive Weighting (SAW) dapat pula disebut sebagai metode penjumlahan terbobot [10][11]. Pada dasarnya metode SAW digunakan untuk mencari penjumlahan terbobot dari rating kinerja pada setiap alternatif di setiap kriteria yang ada. Alternatif yang ada dihauskan untuk melalui proses normalisasi matriks keputusan (X) dengan berdasarkan skala yang berasal dari bobot masing-masing atribut [5].

\section{Teknologi Firebase}

Firebase merupakan teknologi back-end as a service (BaaS) berbasis cloud dari Google yang menyediakan berbagai layanan, salah satunya adalah fitur push notification bernama firebase cloud messaging. Firebase cloud messaging merupakan perkembangan dari Google Cloud Messaging (GCM) yang menyediakan layanan agar developer dapat mengirimkan pesan notifikasi ke perangkat android dari server [3].

\section{E. Teknologi Geotagging}

Geotagging merupakan proses penambahan informasi geospasial pada berbagai media digital. Media yang telah mengalami proses geotagging akan memiliki informasi koordinat berupa longitude, latitude dan altitude. Pada penelitian ini metode Geotagging yang digunakan untuk melakukan penambahan informasi lokasi pada metadata foto adalah Geotagging [4]. gambar 1 merupakan salah

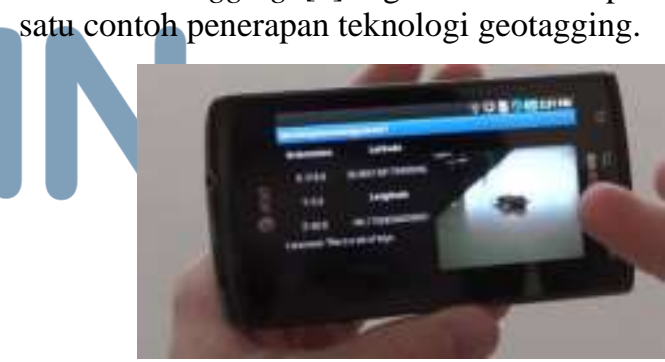

Gambar 1. Teknologi Geotagging

\section{F. Teknologi Google Maps}

Google maps merupakan sebuah layanan peta dunia virtual yang disediakan oleh Google Inc [14]. Google maps dapat dilekatkan sebagai elemen dalam tata letak antarmuka pengguna yang di rancang oleh pemrogram.. Fitur Google Maps ini dapat digunakan secara embeded dalam beberapa bahasa pemrograman termasuk Android melalui sebuah jembatan aplikasi yang disebut Application Programming Interface (API).

\section{Metodologi Penelitian}

Metodologi penelitian yang digunakan dalam penelitian ini adalah metode penelitian terapan, metode ini bertujuan untuk menyelesaikan yang timbul dari 
instansi. Kerangka kerja penelitian dapat dilihat pada gambar 2.

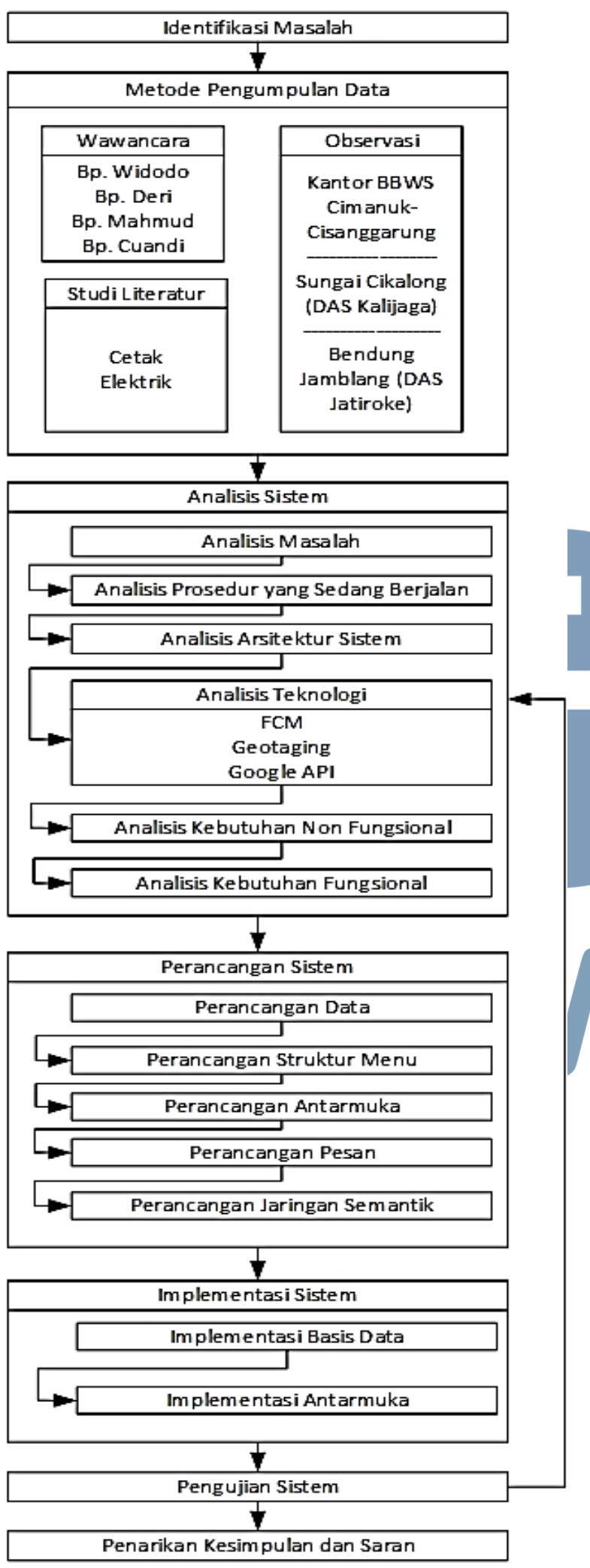

Gambar 2. Kerangka Kerja Penelitian

\section{HASIL DAN PEMBAHASAN}

Tahapan ini terdiri dari gambaran umum sistem, analisis dan perancangan sistem. Langkah terakhir yang dilakukan yaitu melakukan pengujian sehingga dapat diperoleh kesimpulan.

\section{A. Analisis dan Perancangan Sistem}

Sistem yang akan dibangun yaitu aplikasi Android sebagai front-end dan aplikasi web sebagai back-end. Arsitektur Sistem yang akan dibangun dapat dilihat pada gambar 3 dan 4 .

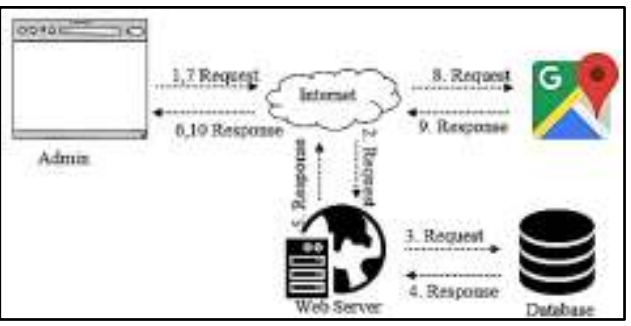

Gambar 3. Arsitektur Sistem Platform Website

Sistem website akan request ke database melalui transportasi internet dan webserver, ketika sudah mendapatkan data dari database, sistem website membutuhkan peta virtual dari Googel Maps API yang akan mengirimkan data latitude dan longitude yang sudah didapat dai database server.

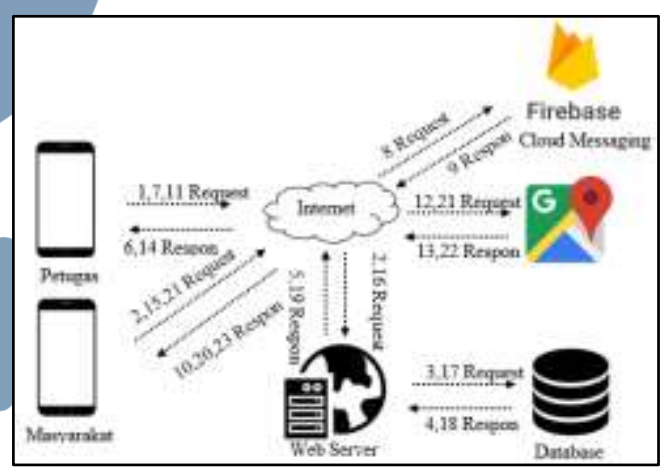

Gambar 4. Arsitektur Sistem Platform Android

Sistem Android petugas akan merequest ke firbase untuk mengirim notifikasi dan Android masyarakat menjadi receive/respon dari firebase sebagai penerima notifikasi dan akan mengambil data notifikasi dari database, kemudian mengirimkan data latitude dan longitude yang akan disimpan dalam database server ke google maps.

B. Analisi Firebase Cloud Messaging

Teknologi Firebase Cloud Message (FCM) digunakan pada untuk memberikan pengumuman sungai akan meluap melalui notifikasi. Teknologi ini diterapkan dalam platform Android, dengan tujuan untuk memberikan kemudahan bagi petugas lapangan dalam menginformasikan pengumuman kepada masyarakat mengenai sungai akan meluap di lapangan. dan memudahkan masyarakat untuk mengetahui 
informasi sungai yang meluap tanpa harus menunggu kabar dari kepala desa atau masyarakat setempat.

Dalam konfigurasi mengirimkan notifikasi dari FCM, menggunakan bantuan bahasa pemrograman PHP seperti script pada gambar 5.

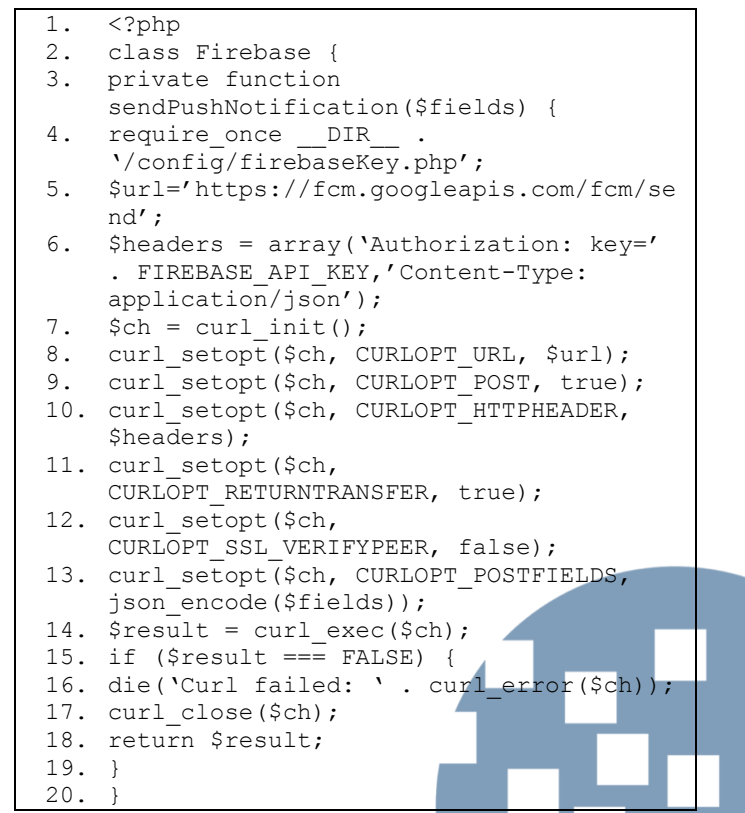

\section{Gambar 5. Script Mengirim Notifikas}

Dalam menerima notifikai dari FCM dapat dilihat pada gambar 6 .

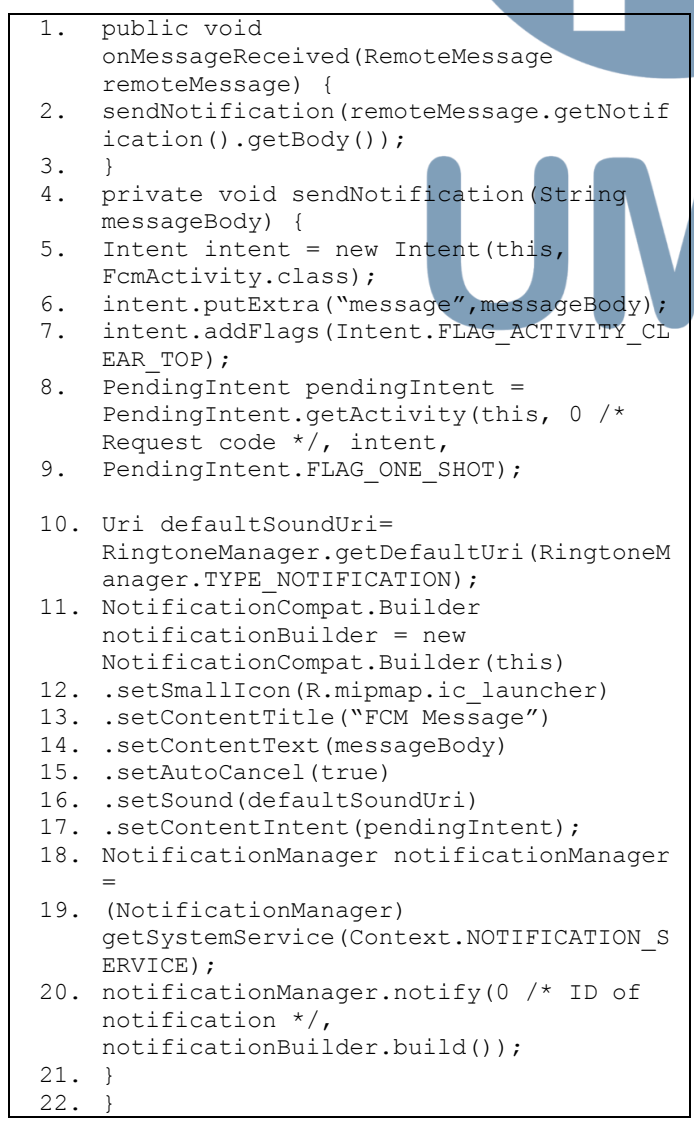

Gambar 6. Script Menerima Notifikasi

\section{Analisis Geotagging}

Teknologi geotagging ini digunakan pada pembangunan untuk memberikan pengumuman dalam sebuah foto tentang mendeteksi letak lokasi sungai meluap. sehingga masyarakat pun mengetahui lokasi sungai yang meluap.

Langkah Geotagging disini menggunakan EXIF (Exchangeable Image File Format) pada GPS Foto. Secara umum, EXIF adalah mengambil data Informasi dari metadata Foto. Langkah Geotagging dapat dilihat pada gambar 7 .

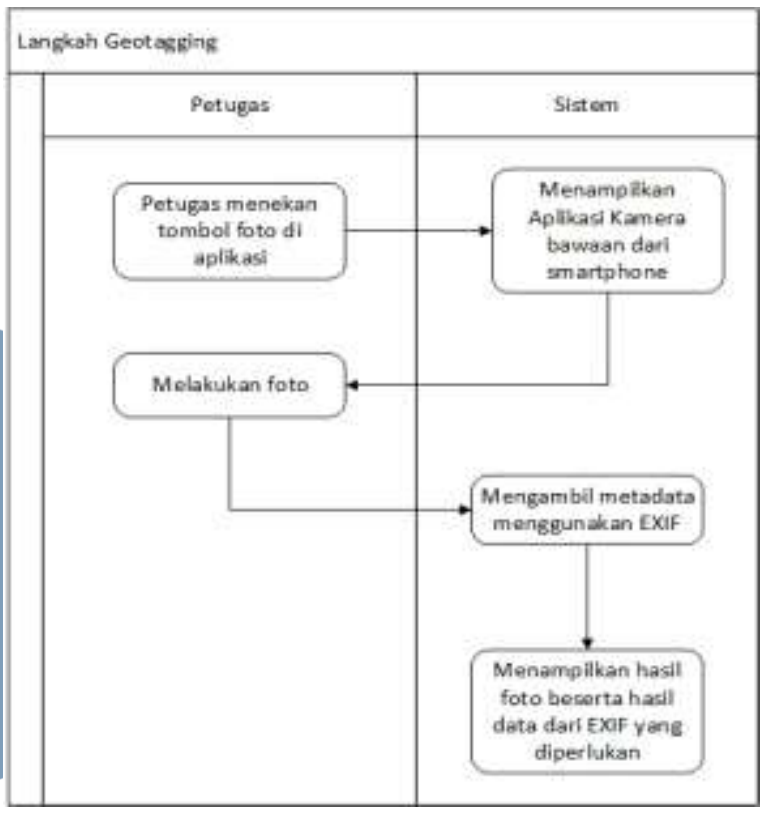

Gambar 7. Langkah Geotagging

D. Analisis Google Maps

Google Maps API yang digunakan dalam untuk mengarahkan masyarakat menuju tempat pengungsian sesuai yang direkomendasikan. Script untuk menuju aplikasi Google Maps yang langsung mengarahkan ke tempat tujuan dapat dilihat pada Gambar 8 .

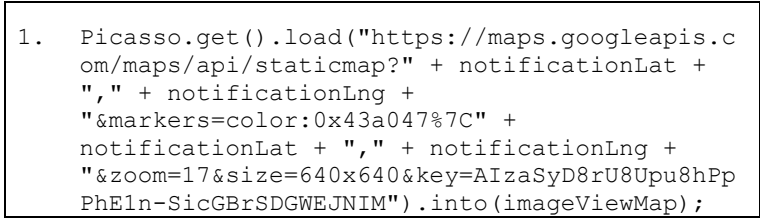

\section{Gambar 8. Script Menuju Lokasi}

\section{E. Analisis Metode SAW}

Kriteria yang dilakukan dalam rekomendasi tempat pengungsian dapat dilihat pada Tabel 1 .

Tabel 1. Kriteria

\begin{tabular}{|l|l|}
\hline \multicolumn{1}{|c|}{ Kriteria } & \multicolumn{1}{c|}{ Penjelasan } \\
\hline Jarak Tempat & $\begin{array}{l}\text { Semakin dekat maka semakin } \\
\text { baik }\end{array}$ \\
\hline Jarak DAS & Semakin jauh semakin baik \\
\hline Lahan & $\begin{array}{l}\text { Bangunan pemerintah lebih baik } \\
\text { dari gedung sekolah, sedangkan } \\
\text { gedung sekolah lebih baik dari }\end{array}$ \\
\hline
\end{tabular}




\begin{tabular}{|l|l|}
\hline \multicolumn{1}{|c|}{ Kriteria } & \multicolumn{1}{|c|}{ Penjelasan } \\
\hline & $\begin{array}{l}\text { tempat ibadah, dan tempat ibadah } \\
\text { lebih baik dari lapangan terbuka. }\end{array}$ \\
\hline Elevasi & $\begin{array}{l}\text { Semakin tinggi maka semakin } \\
\text { baik }\end{array}$ \\
\hline
\end{tabular}

Didalam SAW sendiri dilakukan pembobotan pada masing-masing kriteria yang digunakan untuk melakukan penjumlahan terbobot pada perhitungan SAW. Hasil pembobotan berdasarkan kesepakatan instansi yang dapat dilihat pada tabel 2 sampai tabel 5 .

Tabel 2. Bobot Jarak Tempat Pengungsian

\begin{tabular}{|l|l|c|}
\hline No & Jarak Tempat & Bobot \\
\hline 1 & $0-499 \mathrm{~m}$ & 4 \\
\hline 2 & $500-999 \mathrm{~m}$ & 3 \\
\hline 3 & $1000-1999 \mathrm{~m}$ & 2 \\
\hline 4 & $2000-\infty \mathrm{m}$ & 1 \\
\hline
\end{tabular}

Tabel 3. Pembobotan Kriteria Jarak DAS

\begin{tabular}{|l|l|c|}
\hline No & Jarak Pemukiman & Bobot \\
\hline 1 & $2000-\infty \mathrm{m}$ & 4 \\
\hline 2 & $1000-1999 \mathrm{~m}$ & 3 \\
\hline 3 & $500-999 \mathrm{~m}$ & 2 \\
\hline 4 & $0-499 \mathrm{~m}$ & 1 \\
\hline
\end{tabular}

Tabel 4. Pembobotan Kriteria Tata Guna Lahan

\begin{tabular}{|l|l|c|}
\hline No & \multicolumn{1}{|c|}{ Kelas } & Bobot \\
\hline 1 & Bangunan Pemerintahan & 4 \\
\hline 2 & Sekolah & 3 \\
\hline 3 & Tempat Ibadah & 2 \\
\hline 4 & Lapangan & 1 \\
\hline
\end{tabular}

Tabel 5. Pembobotan Elevasi

\begin{tabular}{|l|l|l|c|}
\hline No & Interval & \multicolumn{1}{|c|}{ Keterangan } & Bobot \\
\hline 1 & $16-\infty \mathrm{m}$ & Sangat Tinggi & 4 \\
\hline 2 & $11-15 \mathrm{~m}$ & Tinggi & 3 \\
\hline 3 & $6-10 \mathrm{~m}$ & Sedang & 2 \\
\hline 4 & $1-5 \mathrm{~m}$ & Rendah & 1 \\
\hline
\end{tabular}

Sedangkan bobot kriteria dapat dilihat pada tabel 6 .

Tabel 6. Bobot Kriteria

\begin{tabular}{|l|l|l|}
\hline Cij & Skor Total & Bobot \\
\hline C1 & Jarak Tempat & $40 \%$ \\
\hline C2 & Jarak DAS & $30 \%$ \\
\hline C3 & Lahan & $20 \%$ \\
\hline C4 & Elevasi & $10 \%$ \\
\hline
\end{tabular}

Contoh kasus metode SAW, kriteria tempat pengungsian dapat dilihat pada tabel 7 .

Tabel 7. Kriteria

\begin{tabular}{|c|l|c|c|c|}
\hline no & $\begin{array}{c}\text { Jarak } \\
\text { Tempat }\end{array}$ & $\begin{array}{c}\text { Jarak } \\
\text { DAS }\end{array}$ & Lahan & Elevasi \\
\hline 1 & 0.7 & 0.81 & Pemerintah & Rendah \\
\hline 2 & 1.51 & 1.82 & Pemerintah & Rendah \\
\hline
\end{tabular}

Berikut tabel alternative kriteria yang dapat dilihat pada tabel 8 .

Tabel 8. Alternatif Kriteria

\begin{tabular}{|c|l|l|l|l|}
\hline \multirow{2}{*}{ Alternatif } & \multicolumn{4}{|c|}{ Kriteria } \\
\cline { 2 - 5 } & C1 & C2 & C3 & C4 \\
\hline Tempat Pengungsian 1 & 3 & 2 & 4 & 1 \\
\hline Tempat Pengungsian 2 & 2 & 3 & 4 & 1 \\
\hline
\end{tabular}

Perhitungan SAW sebagai berikut, Lokasi Tempat Pengungsian 1

$$
\begin{aligned}
& r 11=\frac{3}{(\operatorname{Max}(3,2,4,1))}=\frac{3}{4}=0,75 \\
& r 21=\frac{2}{(\operatorname{Max}(3,2,4,1))}=\frac{2}{4}=0,5 \\
& r 31=\frac{4}{(\operatorname{Max}(3,2,4,1))}=\frac{4}{4}=1 \\
& r 41=\frac{1}{(\operatorname{Max}(3,2,4,1))}=\frac{1}{4}=0,25
\end{aligned}
$$

\section{Lokasi Tempat Pengungsian 2}

$$
\begin{aligned}
& r 12=\frac{2}{(\operatorname{Max}(2,3,4,1))}=\frac{2}{4}=0,5 \\
& r 22=\frac{3}{(\operatorname{Max}(3,2,4,1))}=\frac{3}{4}=0,75 \\
& r 32=\frac{4}{(\operatorname{Max}(3,2,4,1))}=\frac{4}{4}=1 \\
& r 42=\frac{1}{(\operatorname{Max}(3,2,4,1))}=\frac{1}{4}=0,25
\end{aligned}
$$

Hasil dari nilai rating kinerja ternomalisasi

$$
\begin{gathered}
V 1=(0,4 x 0,5)+(0,3 \times 0,75)+(0,2 \times 1)+(0,1 \times 0,25) \\
=0,675 \\
V 2=(0,4 \times 0,75)+(0,3 \times 0,5)+(0,2 \times 1)+(0,1 \times 0,25) \\
=0,65
\end{gathered}
$$

Hasil penilaian terbesar ada pada lokasi tempat pengungsian ke 1 yaitu dengan nilai 0,675 sehingga lokasi tempat pengungsian 1 dapat di jadikan alternatif pertama dalam pemilihan tempat pengungsian.

\section{F. Analisis Sitem}

Analisis sistem membahas beberapa gambaran Umum analisis sistem diantarnya Use Case.

1. Use Case Diagram Platform Android

Use diagram pada platform android terdiri dari login, lupa password, pemberi notif, pencatatan TMA, profil, cari sungai, cari notif, Use case diagram platform Android dapat dilihat pada gambar 9. 


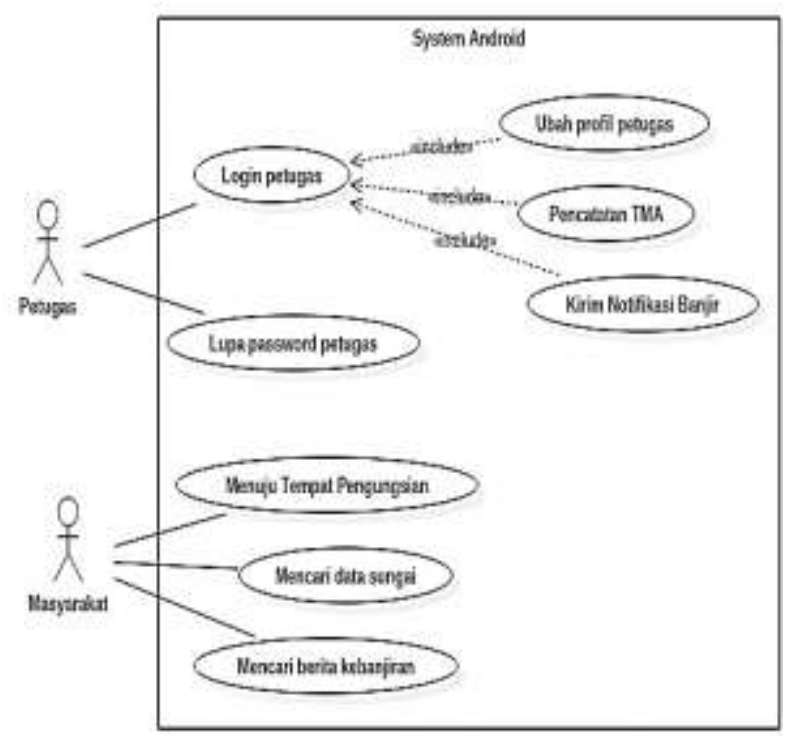

Gambar 9. Use Case Diagram Platform Android

2. Use Case Diagram Platform Website

Use diagram pada platform website terdiri dari login, lupa password, mengelola daerah aliran sungai, mengelola pos, mengelola petugas, mengelola tempat

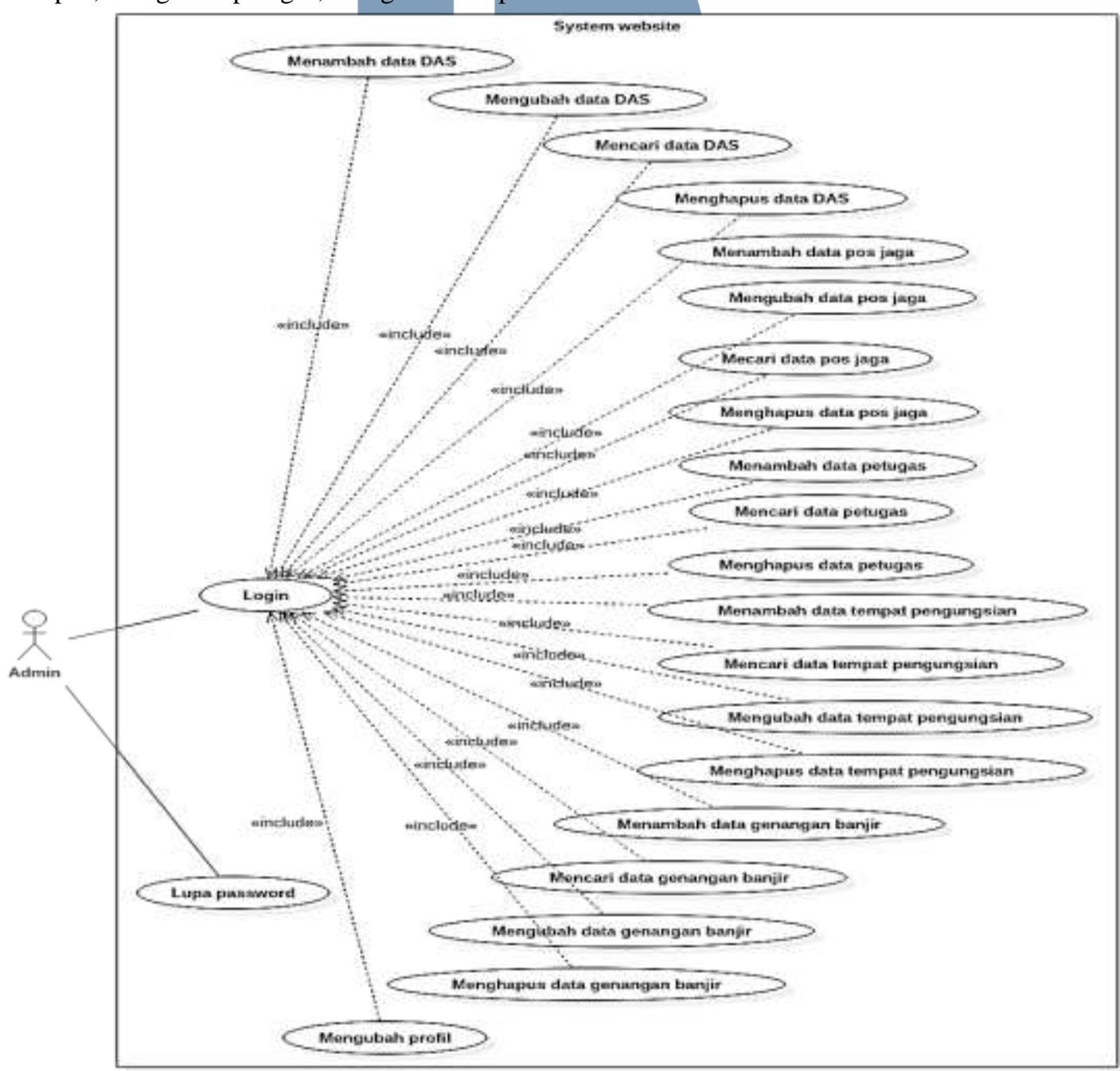

Gambar 10. Use Case Diagram Platform Website pengungsian, mengelola genangan, serta profil. Use case diagram platform website dapat dilihat pada gambar 10. 
G. Implementasi Sistem

Adapun beberapa pembahasan implementasi yang dilakukan antara lain implementasi perangkat keras, perangkat lunak dan antarmuka.

Perangkat keras yang digunakan dalam mengimplementasikan aplikasi, perangkat keras komputer dan smartphone yang dapat dilihat pada tabel 9.

Tabel 9. Implementasi Perangkat Keras

\begin{tabular}{|l|l|}
\hline \multicolumn{1}{|c|}{ Komputer } & \multicolumn{1}{c|}{ Smartphone } \\
\hline Processor @ 1.8 GHZ & $\begin{array}{l}\text { Smartphone Android } \\
\text { 4.4 Kitkat }\end{array}$ \\
\hline DDR3 RAM 2 GB & RAM 1 GB \\
\hline Hardisk 500 GB & Jaringan GSM / CDMA \\
\hline Koneksi internet & Koneksi 4G \\
\hline $\begin{array}{l}\text { Resolusi Layar } \\
\text { 1024x768 piksel }\end{array}$ & Kamera dan GPS \\
\hline
\end{tabular}

Perangkat lunak yang digunakan untuk mengimplementasikan aplikasi yaitu implementasi perangkat lunak pada komputer dan smartphone. Untuk selengkapnya mengenai spesifikasi perangkat lunak dapat dilihat pada tabel 10.

Tabel 10. Implementasi Perangkat Lunak

\begin{tabular}{|l|l|}
\hline \multicolumn{1}{|c|}{ Komputer } & \multicolumn{1}{|c|}{ Smartphone } \\
\hline Sistem Operasi Windows 7 & $\begin{array}{l}\text { Sistem Operasi Android } \\
\text { 4.4 Kitkat }\end{array}$ \\
\hline $\begin{array}{l}\text { Browser: Google Chrome, } \\
\text { mozilla firefox, internet } \\
\text { explorer }\end{array}$ & \\
\hline
\end{tabular}

Implementasi antarmuka terdiri dari platform Android dan Website yang menjelaskan tampilantampilan aplikasi yang sesuai dengan analisis dan perancangan sistem.

a) Antarmuka Platform Android

Tampilan antarmuka Android yang merupakan program front-end.

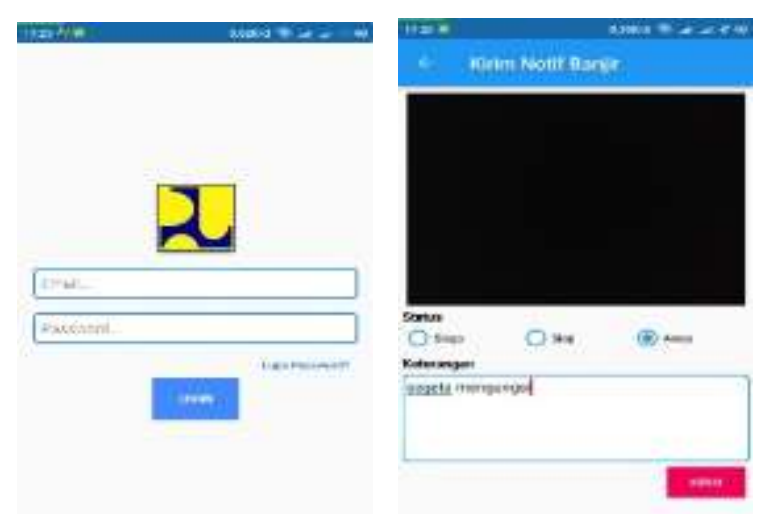

Gambar 11. Tampilan Antarmuka Aplikasi Android Petugas

Pada gambar 11 menunjukkan tampilan login dan pengiriman notifikasi, dimana petugas harus melakukan login terlebih dahulu untuk melakukan kirim notifikasi sungai ke masyarakat. Dengan teknologi Firebase Cloud Messaging (FCM) maka setiap notifikasi akan diterima secara realtime oleh masyarakat melalui smartphone.
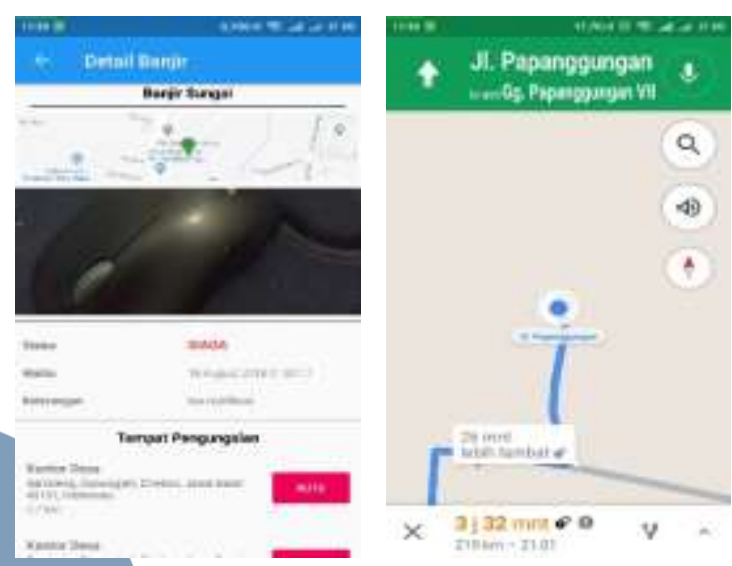

Gambar 12. Tampilan Antarmuka Aplikasi Android Masyarakat

Pada gambar 12, menunjukkan lokasi banjir dan foto sungai serta rekomendasi pengungsian, ketika masyarakat memilih salah satu tempat, aplikasi mengarahkan ke aplikasi Google maps untuk mengarahkan masyarakat ke tempat pengungsian.

Aplikasi ini menyaratkan bahwa pengguna harus mengaktifkan terlebih dahulu sensor Global Positioning System (GPS) pada smartphone untuk mengetahui lokasi pengguna, sehingga informasi petunjuk rute pengungsian dapat disajikan lebih akurat.

b) Antarmuka website

Tampilan antarmuka website yang merupakan program back-end.

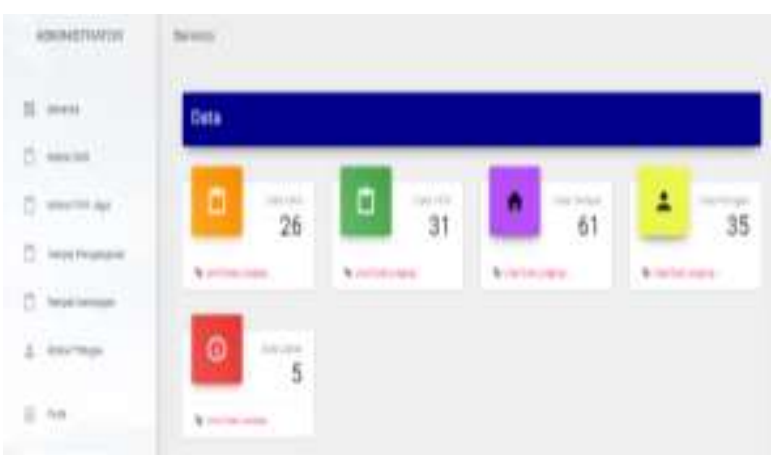

Gambar 13. Tampilan Home Website 


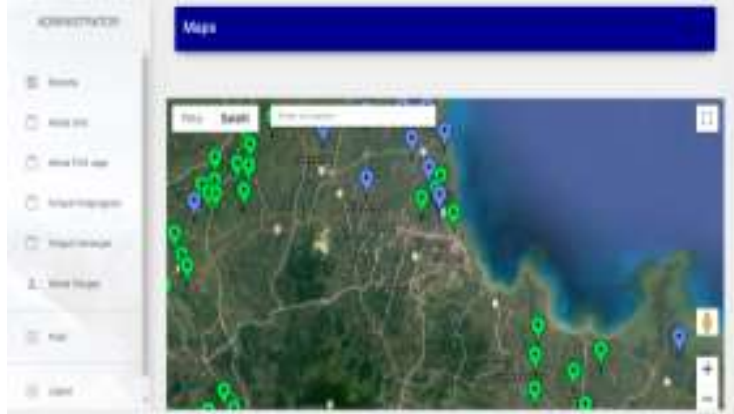

Gambar 14. Tampilan Lokasi Website

Pada gambar 13 dan 14, menunjukkan home website meluputi jumlah data dan kumpulan titik lokasi tempat.

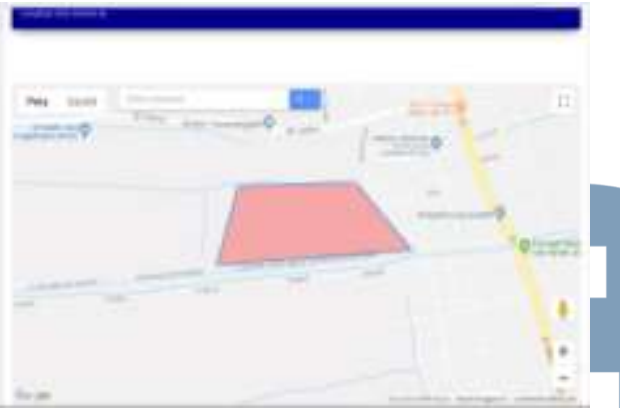

Gambar 15. Tampilan Antarmuka Genangan Banjir

Pada gambar 15, menunjukkan gambar lokasi genangan air dengan Polygon.

\section{H. Pengujian Sistem}

Pengujian dilakukan secara langsung dengan petugas dan masyarakat. Tahapan ini menggunakan kuisioner. Hasil kuisoner petugas lapangan sungai dengan responden sebanyak 12 orang yang dilakukan di kantor BBWS Cimanuk-Cisanggarung pada bulan Agustus 2018, dapat dilihat pada Tabel 11.

Tabel 11. Hasil Kuisioner Petugas

\begin{tabular}{|c|c|c|c|c|c|c|}
\hline No & \multicolumn{5}{|c|}{ Pertanyaan } & Hasil \\
\hline \multirow[t]{3}{*}{1} & \multicolumn{5}{|c|}{$\begin{array}{l}\text { Apakah anda setuju bahwa perangkat } \\
\text { lunak ini dapat mempermudah anda } \\
\text { dalam melaporkan sungai yang akan } \\
\text { meluap kepada masyarakat? }\end{array}$} & \multirow[t]{3}{*}{$86,6 \%$} \\
\hline & SS & $\mathrm{S}$ & RR & TS & STS & \\
\hline & 6 & 4 & 2 & 0 & 0 & \\
\hline \multirow[t]{3}{*}{2} & \multicolumn{5}{|c|}{$\begin{array}{l}\text { Apakah anda setuju bahwa perangkat } \\
\text { lunak ini sudah berhasil menyertakan } \\
\text { lokasi pengambilan foto sungai yang } \\
\text { akan meluap? }\end{array}$} & \multirow[t]{3}{*}{$71,6 \%$} \\
\hline & SS & $\mathrm{S}$ & RR & TS & STS & \\
\hline & 0 & 7 & 5 & 0 & 0 & \\
\hline \multirow[t]{3}{*}{3} & \multicolumn{5}{|c|}{ Apakah anda setuju bahwa perangkat } & \multirow[t]{3}{*}{$93,3 \%$} \\
\hline & SS & $\mathrm{S}$ & RR & TS & STS & \\
\hline & 8 & 4 & 0 & 0 & 0 & \\
\hline \multirow[t]{3}{*}{4} & \multicolumn{5}{|c|}{$\begin{array}{l}\text { Apakah anda setuju bahwa perangkat } \\
\text { lunak ini mudah digunakan? }\end{array}$} & \multirow[t]{3}{*}{$76,6 \%$} \\
\hline & SS & $\mathrm{S}$ & RR & TS & STS & \\
\hline & 2 & 6 & 4 & 0 & 0 & \\
\hline
\end{tabular}

Hasil kuisioner masyarakat dengan responden sebanyak 9 orang yang dilakukan di daerah aliran sungai Jatiroke pada bulan Agustus 2018, dapat dilihat pada Tabel 12. Jumlah responden sewaktu pengujian memang masih terbatas namun akan diujikan kembali setelah ada penambahan fitur yang lain seperti SMS gateway dan API Weather pada penelitian selanjutnya.

Tabel 12. Hasil Kuisioner

\begin{tabular}{|c|c|c|c|c|c|}
\hline No & \multicolumn{4}{|c|}{ Pertanyaan } & Hasil \\
\hline \multirow[t]{3}{*}{1} & \multicolumn{4}{|c|}{$\begin{array}{l}\text { Apakah Anda setuju bahwa perangkat } \\
\text { lunak ini dapat mempermudah Anda } \\
\text { dalam mendapatkan informasi sungai } \\
\text { yang akan meluap yang mengakibatkan } \\
\text { bencana banjir? }\end{array}$} & \multirow[t]{3}{*}{$75,5 \%$} \\
\hline & SS & $\mathrm{S}$ & $\mathrm{RR}$ & TS & \\
\hline & 1 & 5 & 3 & 0 & \\
\hline \multirow[t]{3}{*}{2} & \multicolumn{4}{|c|}{$\begin{array}{l}\text { Apakah Anda setuju bahwa perangkat } \\
\text { lunak ini dapat mempermudah Anda } \\
\text { dalam menemukan lokasi tempat } \\
\text { pengungsian? }\end{array}$} & \multirow[t]{3}{*}{$73,3 \%$} \\
\hline & SS & $\mathrm{S}$ & RR & $\mathrm{TS}$ & \\
\hline & 0 & 6 & 3 & 0 & \\
\hline \multirow[t]{3}{*}{3} & \multicolumn{4}{|c|}{$\begin{array}{l}\text { Apakah Anda setuju bahwa perangkat } \\
\text { lunak ini dapat membantu anda dalam } \\
\text { mengarahkan Anda menuju lokasi } \\
\text { tempat pengungsian yang Anda pilih? }\end{array}$} & \multirow[t]{3}{*}{$68,9 \%$} \\
\hline & SS & S & RR & TS & \\
\hline & 0 & 4 & 5 & 0 & \\
\hline \multirow[t]{3}{*}{4} & \multicolumn{4}{|c|}{$\begin{array}{l}\text { Apakah anda setuju bahwa perangkat } \\
\text { lunak ini mudah digunakan? }\end{array}$} & \multirow[t]{3}{*}{$86,7 \%$} \\
\hline & SS & S & RR & TS & \\
\hline & 3 & 6 & 0 & 0 & \\
\hline
\end{tabular}

Rata-rata hasil akhir kusioner, sebagai berikut:

Petugas : $\frac{(86,6+71,6+93,3+76,6)}{4}=82,03 \%$

Masyarakat : $\frac{(75,5+73,3+68,9+86,7)}{4}=76,1 \%$

Berdasarkan hasil rata-rata pengujian dengan metode kuisioner yang telah disebarkan kepada petugas BBWS Cimanuk-Cisanggarung dan perwakilan masyarakat daerah sungai Jatiroke, menyatakan bahwa nilai yang diperoleh petugas yaitu $82,03 \%$ yang menunjukkan bahwa aplikasi ini dapat membantu petugas lapangan sungai dalam pemberian pengumuman sungai yang akan meluap. Sedangkan nilai rata-rata kuisioner masyarakat yaitu $76,1 \%$ yang menunjukkan bahwa aplikasi ini cukup membantu masyarakat dalam mendapatkan informasi luapan sungai dan beberapa tempat pengungsian.

\section{SIMPULAN}

Adapun kesimpulan bahwa penelitian ini dapat membantu petugas lapangan sungai dalam memberikan pengumuman kepada masyarakat dan cukup membantu masyarakat menerima informasi sungai akan meluap dengan lokasinya menggunakan teknologi Firebase Cloud Messaging dan teknologi Geotagging serta dapat menuju tempat pengungsian yang direkomendasikan dengan bantuan teknologi Google Maps.

\section{DAFTAR PUSTAKA}

[1] A. Setiyadi dan E. B. Setiawan, "Sistem Informasi Pengumuman Program Studi Di Perguruan Tinggi X," Lontar Komputer, vol. 8, no. 1, pp. 11-21, 2017. 
[2] F. D. Nurzam, I. N. Fajri dan D. Prabowo, "Rancang Bangun Aplikasi Media Laporan Aspirasi Dengan Firebase Cloud Messaging Berbasis Mobile," Proseding Seminar Nasional Teknologi Informasi dan Multimedia 2017, vol. 5, no. 1, pp. 37-42, 2017.

[3] W. Wijaya, H. Tolle dan A. P. Kharisma, "Rancang Bangun Aplikasi Geotagging Social Report Bencana Banjir," Jurnal Pengembangan Teknologi Informasi dan Ilmu Komputer, vol. 2, pp. 2817-2824, 2018.

[4] J. A. J. L. Batu dan C. Fibriani, "Analisis Penentuan Lokasi Evakuasi Bencana Banjir dengan Pemanfaaan Sistem Informasi Geografis dan Metode Simple Addtive Weighting," Teknologi Informasi dan Ilmu Koтputa, vol. 4, no. 2, pp. 127135, 2017.

[5] E. Juanianto dan M. Z. Zuhdi, "Penerapan Metode Palette untuk Menentukan Warna Dominan dari Sebuah Gambar Berbasis Android," Informatika, vol. 5, no. 1, pp. 62-73, 2018.

[6] M. Z. Faried, A. Mulwinda dan Y. Primadiyono, "Pengembangan Aplikasi Android Bimbingan Skripsi dengan Fitur Notifikasi," Jurnal Teknik Elektro, vol. 9, no. 2, pp. 7479, 2017.

[7] T. Ismail, A. Mulyana dan U. A. A. Ahmad, "Perancangan dan Implementasi Sistem Informasi Geografis : Sistem Pemantauan Banjir Berbasis Web," e-Procceding of Engineering, vol. 2, no. 1, pp. 611-618, 2015.

[8] F. Falanda, R. Gustriansyah dan Hartini, "Penentuan Objek Wisata, Objek Kuliner Serta Akomodasi Disekitar Pengguna Dikota Palembang dengan Menggunakan Algoritma Euclidean Distance," Jurnal Imliah Informatika Global, vol. 7, no. 1, pp. 17-24, 2016.

[9] N. Eka P, S. W. Sihwi dan R. Anggaraningsih, "Sistem Penunjangan Keputusan untuk Menentukan Lokasi Usaha dengan Metode Simple Additive Weighting," ITSMART, vol. 3, no. 1, pp. 41-46, 2014.

[10] H. Sugiarto, "Penerapan Metode Simple Additive Weighting untuk Pemilihan Perumahan," Computer and Information Techonology, vol. 1, no. 1, pp. 96-103, 2016.

[11] T. Suryana dan Koesheryatin, Aplikasi Internet Menggunakan HTML, CSS, \& JavaScript, Jakarta: PT Elex Media Komputido, 2014.

[12] Zelpida dan 0044esriyeni, "Pemanfaatan Teknologi Informasi di Perpustakaan Pengadilan Tinggi Padang," Ilmu dan Infoormasi Perpustakaan dan Kearsipan, vol. 4, no. 1, pp. 73 80, 2015.

[13] N. G. Perdana dan T. Widodo, "Sistem Pendukung Keputusan Pemberian Beasiswa Kepada Peserta Didik Baru Menggunakan Metode TOPSIS," Semantik, vol. 3, no. 1, pp. 265-272, 2013.

[14] Armanto, "Aplikasi Persebaran Objek Wisata di Kota Depok Berbasis Mobile GIS Memanfaatkan Smartphone Android," Komunikasi, Media dan Informatika, vol. 6, no. 1, pp. 57-64, 2017. 